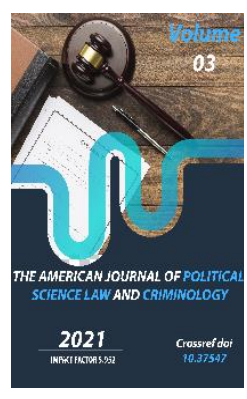

\title{
Judicial And Legal Reforms At A New Stage
}

\author{
Saydakhmedov Umid Murodovich \\ PhD, Associate Professor Of The Department Of "Economic Law" Supreme School Of Judges At \\ The Supreme Judicial Council Republic Of Uzbekistan
}

Journal Website: https://theamericanjou rnals.com/index.php/ta jpslc

Copyright: Original content from this work may be used under the terms of the creative commons attributes 4.0 licence.

\section{ABSTRACT}

This article highlights the reforms carried out in the field of judiciary in Uzbekistan today, its essence, the issues of ensuring reliable protection of the rights and interests of citizens and business entities protected by law through the court are covered. Also, the article analyzes the radical reform of the judicial system in the last 4 years, the establishment of a new judicial system in the country as a result of reforms, in particular, the implementation of major reforms in the system of selection and appointment of judges, openness to the judicial system and the introduction of information and communication systems in this area.

\section{KEYWORDS}

Judicial, reforms, rights, protect, regulate, analyze, transparency, information, technology, activity.

\section{INTRODUCTION}

\section{Courts Republic of Uzbekistan: current state and development prospects}

An independent and strong judiciary is a key factor in a democratic State governed by the rule of law.

In recent years, at the initiative of the President of Uzbekistan Shavkat Mirziyoyev, a radical reform of the judicial and legal system has been carried out in the country, which is expressed in strengthening measures to reliably protect the rights and legitimate interests of citizens and entrepreneurs, effectively ensure justice, and increase the role of the judicial community. Uzbekistan has entered a new stage of its development, which is based on a five - year 
Strategy of Action and a national idea: "From national revival - to national progress".

The policy of ensuring human rights and freedoms and protecting private property is consistently implemented, which ensures internal stability and receives recognition from the international community. In the process of ensuring human rights and freedoms, the rule of law, a new democratic image of the state is being created.

Judges, as representatives of an independent judiciary, contribute to the successful development of the country, which is facilitated by the reform of the judicial and legal system.

Over the past four years, more than forty laws and regulations have been adopted in the area of judicial reforms. They have had a major positive impact, both on the organization of the judicial system and on the practice of handling court cases.

It is worth mentioning the Decree of the President of the Republic of Uzbekistan "On measures to radically improve the structure and increase the efficiency of the judicial system of the Republic of Uzbekistan", according to which a unified state Register of Legal Entities was created. The Supreme Court, the highest body of judicial power in the field of civil, criminal, administrative and economic proceedings, which strengthened the judicial power and created conditions for the uniformity of judicial law enforcement practice.

A new constitutional body is constantly working to assist in ensuring compliance with the constitutional principle of independence of the judiciary in the Republic of Uzbekistan Supreme Judicial Council. It consists of judges, representatives of the legal and scientific community, and civil society institutions.

This body was formed, among other things, taking into account the recommendations of the Kiev Conference on the Independence of the Judiciary of the Bureau for Democratic Institutions and Human Rights of the Organization for Security and Co-operation in Europe. It is the Council that has the authority to select and form a highly qualified judicial corps.

It should be noted that the introduction of this institution allowed for an open and transparent formation of the judicial corps on the basis of a competitive selection of candidates for judicial positions from among the most qualified specialists, to ensure the true inviolability of judges and prevent interference in their activities in the administration of justice, to establish a dialogue of the judicial community with the population. In the course of the reform, qualification requirements and mechanisms for selecting candidates for judicial positions have been strengthened. The age limit for candidates for judges has been raised to 35 years.

Judges are now appointed or elected for an initial five-year, subsequent ten-year and indefinite term of office, which ensures the stability of the judiciary and strengthens the independence of judges.

This innovation fully meets the requirements of modern international and foreign experience. In accordance with article 12 of the UN Basic Principles on the Independence of the Judiciary 
of 29 November 1985, judges who are appointed or elected have a guaranteed term of office until mandatory retirement or expiration of their term of office, where applicable. In practice, this means that a judge retains his or her position until he or she reaches the age limit.

This measure has become the main guarantee of the permanent status of judges - one of the most important elements of their independence. It is significant that at present this norm is fully implemented in the law enforcement practice of our country. Uzbekistan has consistently developed organizational and legal mechanisms aimed at ensuring comprehensive protection of judges, as well as their immunity.

Liability for interference in the activities of judges in the administration of justice is established. The legislation stipulates that influencing judges in any form in order to prevent a comprehensive, complete and objective consideration of a particular case or to obtain an illegal court decision entails criminal liability in accordance with the law.

Specifically, for this purpose, the Supreme Judicial Council has created a special structure that ensures the inviolability of judges. This structure actually protects judges from the above-mentioned illegal interference in their activities, which also strengthens their independence and inviolability.

The existing procedure for training candidates for judicial positions has changed dramatically. The Supreme School of Judges operates successfully, providing advanced training of judges on the basis of the educational process as close as possible to judicial practice. The new educational system makes it possible to improve candidates' theoretical knowledge, train them in professional ethics, psychology, business communication and time management skills, negotiation tactics, information technology, and interpretation and application of legal norms.

In recent years, significant work has been carried out to establish the court as an independent and independent branch of government, transforming it from a repressive body in the past into a truly independent institution of the state, designed to reliably protect and protect human rights and freedoms.

Adopted in the first years of independence Criminal and Criminal Procedure Codes The Republic of Uzbekistan has laid the legal foundation for effective protection of individuals from criminal attacks, protection of the rights and freedoms of citizens, the interests of society and the State, and ensuring the rule of law and order.

Over the past years, the criminal and criminal procedure legislation has undergone significant changes aimed at improving its norms, implementing advanced international standards and foreign practices in order to unconditionally ensure the rights and freedoms of citizens involved in criminal proceedings.

In particular, criminal legislation was further liberalized and certain categories of crimes were decriminalized, and the list of noncustodial sentences was expanded.

Comprehensive measures have been implemented to expand the scope of the Habeas Corpus Institute, introduce a simplified 
procedure for criminal proceedings, and further strengthen guarantees of citizens' rights and freedoms in judicial and investigative activities.

Since the beginning of 2021, the principle of "one court-one instance" has been implemented:

- Courts of general jurisdiction of the Republic of Karakalpakstan, regions and the city of Tashkent were formed on the basis of regional and equivalent courts for civil cases, criminal cases and economic courts, while maintaining strict specialization of judges and forming separate judicial boards by types of legal proceedings;

- The powers of administrative courts to consider cases of administrative offenses have been transferred to criminal courts;

- Inter-district administrative courts have been established in the centers of the Republic of Karakalpakstan and regions, the city of Tashkent, specializing in the consideration of cases arising from administrative and other public legal relations, with the abolition of district (city) administrative courts in this regard and the preservation of administrative courts of the Republic of Karakalpakstan, regions and the city of Tashkent;

- The right to appeal decisions of the Supreme Qualification Board of Judges of the Republic of Uzbekistan, as well as qualification boards of judges of courts of the Republic of Karakalpakstan, regions and the city of Tashkent is granted to the Supreme Judicial Council.

The institution of supervisory review of court cases was abolished, as well as the rights of the
Chairman of the Supreme Court, the Prosecutor General of the Republic of Uzbekistan and their deputies to file a supervisory protest against court decisions, sentences, rulings and decisions were abolished.

So, if before 2017 , according to the procedural legislation, there were six instances of consideration of court cases, but now these instances have become four.

First instance district (city) courts, (in some complex cases, regional courts);

Appeal instance (regional courts), (in some complex cases considered by regional courts, the Supreme Court;

Cassation instance (Supreme Court);

Repeated cassation review (based on the protest of the Chairman of the Supreme Court, the Prosecutor General of the Republic of Uzbekistan or their deputies).

As a result of the introduction of the one-courtone-instance principle, the quality of case handling has improved in a short period of time, and citizens' confidence in the courts has increased.

Historical transformations have been implemented that will allow improving and optimizing the judicial system of Uzbekistan, taking into account modern requirements and international standards in the field of justice. The law eliminates unnecessary bureaucratic obstacles in providing judicial protection and eliminates duplicate stages of reviewing judicial acts. The judicial system has been brought in line with modern international standards in order to increase the level of 
access of citizens and entrepreneurs to justice and improve the quality of court proceedings.

\section{Transparency of judicial systems}

Transparency of the judicial system, ensuring awareness of decisions taken, the rights and freedoms of citizens, protecting legitimate interests, and introducing legal mechanisms of public control over the judicial system are important tasks for the further development of democratic reforms in our country.

Ensuring the openness and transparency of the judicial system and the openness of judicial proceedings are important components of democratic procedural forms of judicial proceedings and serve as an important legal guarantee in ensuring the rule of law and the rights of participants in judicial proceedings.

Transparency of judicial activity strengthens people's confidence in the judicial system, media coverage of open trials ensures public control over the judicial system and is of great educational importance.

One of the important stages of ensuring the transparency of judicial proceedings was the adoption of the Resolution of the Plenum of the Supreme Court №4 of February 21, 2020 "On ensuring the transparency of judicial proceedings and the right to information about the activities of courts".

The openness of court sessions is ensured by hearing cases in open court sessions, access to which is not restricted, that is, every person who has shown an interest in hearing the case can freely be in the courtroom during the consideration of the case.
But at the same time, representatives of the media, along with being present as listeners of the trial, were not always allowed to enter the hall as journalists.

This resolution explains that transparency of judicial proceedings, timely and objective informing of the public about the activities of courts, raising the level of legal awareness in society are an important guarantee of justice, public control over the judicial system and an effective tool for increasing public confidence in the judicial system.

If the participation of media representatives in the court session was provided for by law, this norm was declarative. This resolution clarified the procedure for allowing media representatives to participate in the court session. That is, in open court sessions, video and audio recordings can be made with the permission of the presiding judge or the judicial board.

Currently, the system of online broadcasting of trials has been launched and continues to be gradually implemented in all courts, which allows you to monitor the progress of cases in the courts of the republic on the website of the Supreme Court.

In the courts of Uzbekistan, there are no restrictions on the presence of representatives of the mass media, including television, in open trials. With the permission of the presiding judge, representatives of the mass media may take photos and videos during the court session or part of it.

All these measures fully ensure the openness and transparency of the administration of justice. 


\section{Introduction of modern information and communication technologies in the activities of courts.}

One of the important areas of reforms is the introduction of modern information and communication technologies in the judicial system, timely consideration of citizens' appeals.

One of the starting points for ensuring the transparency of the judicial system was the Decree of the President of the Republic of Uzbekistan dated July 13, 2018 "On measures to further improve the judicial and legal system and increase confidence in the judicial authorities", in accordance with which the practice of the procedure for systematic publication of court decisions on the website of the Supreme Court of the Republic of Uzbekistan was introduced, clarification of the content of the adopted judicial document to the participants of the trial after its announcement was introduced into judicial practice.

Much attention is paid to the introduction of the latest information technologies in the work of courts. To date, all courts have implemented an electronic court procedure system that allows remote consideration of court cases.

In addition, the system allows civil and economic courts to accept claims and applications in electronic format. In the first year of the system's operation alone, civil courts received more 440 than 440,000 applications through the electronic court procedure system, which accounted for 40 percent of all applications received. With the help of the system, citizens and legal entities can pay state fees, court costs, fines, and other penalties determined by a court decision to the state budget, and receive notifications and court decisions in electronic form. The system provides access to information about the location of courts, the date and time of consideration of all court cases, and the ability to view any court decision in full or anonymized form. Some of the information is available in the Internet bot associated with the system.

In accordance with the recommendations of the monitoring mission of the Organization for Economic Cooperation and Development, automatic distribution of cases has been introduced in all courts of Uzbekistan using the system.

The system keeps records of court cases, controls the terms of their consideration, forms an automated unified database of court documents and court reports.

In his Message to the Oliy Majlis of the Republic of Uzbekistan on December 29, 2020, the President stressed that "Further expansion of the digitalization of the judicial system will create an opportunity for our citizens to submit appeals online, without having to visit court buildings. Also, citizens will be able to remotely monitor the progress of consideration of their applications."

To date, the courts of the Republic of Uzbekistan are equipped with modern means of information and communication technologies, a single electronic database has been introduced, a video conferencing system makes it possible to hold open court sessions, ensuring the participation of parties and participants in the process who are located in different regions of the republic at the same time. This advantage made it possible to 
consider the merits of the case in a short time, save money on ensuring the presence in the courtroom of both convicted persons, to be punished by the type of imprisonment, and all other participants in the process.

Since October 2018, the courts of first instance have fully implemented software that allows them to automatically distribute cases evenly among judges, excluding the human factor, based on the principles of fairness and impartiality.

Statistics: $1,862,076$ cases, including 75,506 in criminal courts, 363,034 in civil courts, 979,300 in administrative courts, 444,236 in economic courts, were distributed among judges automatically.

In April 2018, the practice of sending courtissued enforcement documents signed with a judge's electronic digital signature to enforcement agencies in electronic form was introduced using the integration of information systems of the Supreme Court and the Enforcement Bureau.

Statistics: $1,442,820$ executive documents, including 67,742 by criminal courts, 524,657 by civil courts, 341,893 by administrative courts, 508,528 by economic courts, were sent electronically through the information system.

Since January 2019, the practice of forming cases in electronic form in economic courts has been launched in order to store case documents exclusively in electronic form and create an electronic archive.

Statistics: 27,543 electronic economic cases were generated.
On June 1, 2020, an electronic archive was created in the information system for the purpose of separate archiving of court cases formed in electronic form.

Statistics: 12,850 cases were sent to the electronic archive.

Starting from September 2014, the procedure for holding court sessions using a video conferencing system was introduced.

This system has the following advantages:

- Participation in court sessions without the need for participants to leave their region;

- Saving time and money of citizens when participating in the court process;

- Full provision of the parties ' participation in the legal process.

Statistics: 207 courtrooms are fully equipped with this system, 24,875 court sessions were held in this mode, according to the results of which 57,999 participants saved 17.7 billion soums.

Since February 1, 2019, the procedure for sending to the courts by administrative bodies data on the collected documents of cases of administrative offenses and obtaining information related to the consideration of the case, exclusively through the integration of the information system in electronic form, has been introduced.

Statistics: This system received information about 792,639 administrative cases.

Since February 1, 2020, the procedure for sending data on collected documents of criminal cases to the courts by investigative bodies and obtaining information related to 
the consideration of the case has been introduced exclusively through the integration of an information system in electronic form.

Statistics: Information on 26,748 criminal cases was received through this system.

One of the most important tasks is to increase the efficiency of judicial proceedings, open information about the activities of courts, as well as improve information systems and resources that expand the list and improve the quality of interactive services provided to the population and business entities.

The Supreme Court has also done some work in this direction.

In particular, for the purpose of using interactive services provided by courts to individuals and legal entities at a single address, informing the public about the types of interactive services provided by courts at a single address, and simplifying the procedure for using interactive services provided by courts to individuals and legal entities. Interactive Services Portal Supreme Court (my.sud.uz).

The portal provides the following interactive services to the population and business entities:

In January 2018, in the "Request" section (exsud.sud.uz) it is possible to send appeals to the courts in electronic form, monitor the process of their consideration online, and receive court decisions in electronic form.

In April 2019 implemented, a unified electronic payment system was introduced for recording state fees and court fees through the "Electronic Payment System" section (billing.sud.uz) in order to create the following amenities:

- When making payments for applying to the court, the bank settlement account and other details are not filled in manually;

- Payments made do not require a separate payment confirmation from the bank;

- Payment can be made in any way (including through the electronic mobile payment systems “CLICK”, "Payme” and “Upay”);

- Payments made on the basis of a court decision are also made through this system and there is no need to provide the court with supporting information.

This system is used to ensure the efficiency and accuracy of mandatory payments made when citizens and entrepreneurs apply to the court.

Statistics: 7008 payments worth $\$ 9.8$ billion were made through the system.

In December 2018, the practice of systematic publication of court decisions that have entered into legal force was introduced in the “Decision Bank" section (public.sud.uz).

Statistics: $1,444,248$ court decisions were including 81,730 by criminal courts, 361,336 by civil courts, 724,610 by administrative courts, and 276,572 by economic courts.

In January 2018, in the "Samples" section (template.sud.uz) posted samples of claims and applications to civil and economic courts.

In January 2018, in the "Calculator" section (calculate.sud.uz there is an electronic calculator that automatically calculates the amount of state duty that must be paid when applying to civil and economic courts. 
In September 2018, an opportunity was created to get acquainted online with the list of cases scheduled for consideration in the first, appeal and cassation instances, through the "Schedule" section (jadval.sud.uz).

In February 2020, a system of remote online registration for a personal appointment with the leadership of the Supreme Court was introduced through the "Electronic reception" section (qabul.sud.uz).

In June 2020, in the section "Online tracking" (my.sud.uz) in test mode, an information system is placed that allows you to track online the progress of consideration of appeals, regardless of their form of submission to the court.

In order to digitalize the activities of judicial authorities, determine measures to improve the exchange of information between courts and other departments, and bring this area to the next level, on September 3, 2020, the President signed Decree №PD-4818 “On measures to digitalize the activities of judicial authorities".

This resolution sets the following tasks for the further stage of digitalization of the activities of judicial authorities:

Expanding the types of interactive electronic services provided to citizens and business entities, ensuring online monitoring of the process of reviewing each application, creating the possibility of free use of interactive services in court buildings;

Further expansion of electronic mutual data exchange with ministries, departments and other organizations to ensure prompt acceptance of information necessary for the administration of justice in the courts;

Ensuring openness and transparency of the judicial community's activities through the introduction of special information programs;

Expanding the possibility of remote participation in court sessions, including through mobile devices and other forms of electronic interaction, as well as creating conditions for receiving court decisions online by the parties to the case in online mode;

Strengthening measures to ensure information and cybersecurity of information systems, databases and other software products, as well as comprehensive protection of official information and data of judicial authorities.

In order to implement these tasks, the program of digitalization of the activities of judicial authorities in 2020-2023 was approved, which provides for:

Recording of court sessions in all courts by means of audio recording based on the request of the parties to the case and with the consent of the presiding judge, as well as forming minutes of court sessions using this system;

Automatic distribution of cases between judges in courts of appeal and cassation instance;

Notify all participants of the time and place of the court session by sending SMS messages on a free basis;

Submission of court decisions to the parties in the case online, at their request - in paper form; 
Organization of providing about 10 interactive services in order to create convenience in the activities of judicial authorities, including citizens and business entities, in achieving justice.

In addition, it is being implemented in the activities of courts Complex of information systems "Adolat", which provides the following features:

Submission of claims, applications and complaints to the courts by state and administrative authorities, local state authorities, economic management bodies and lawyers exclusively in electronic form;

Monitoring by interested parties of the processes of consideration of claims, applications and complaints online;

Sending information and documents by participants of the court session in electronic form;

Automatic generation of court documents using an information system implemented in the activities of courts.

One of the important tasks in the next phase of digitalization activities of the courts is to develop a mobile app that provides the opportunity to participate in court proceedings in the video mode with the introduction of it into practice, as well as the establishment of a system ensuring the participation of persons placed in institutions for the execution of the punishment in the judicial process and personal methods of guiding ships directly from the places of their deployment through video conference.
In October 2020, in the section "Video Conferencing" (vka.sud.uz) has introduced mobile video conferencing in a pilot mode, which allows you to participate in court sessions from anywhere in the world using modern means (gadgets).

Statistics: 78 court sessions were held using this system.

Since October 2020, a video conferencing system has been installed between courts and institutions for the execution of sentences система видеоконференцсвязи.

The introduction of this system eliminated the need to escort defendants and prisoners, as well as other persons involved in the case, in order to ensure their participation in court sessions.

Statistics: 913 court sessions were held using this system.

From January 1, 2021, a system for recording court sessions in all courts was introduced by means of audio recordings based on the request of the parties to the case and with the consent of the presiding judge, as well as the formation of court minutes using this system.

Statistics: thanks to the installation of audio recording equipment in 395 courtrooms, it is possible to conduct court sessions using this system in 583 courts.

A procedure has been introduced for courts to obtain the necessary information and documents directly from state bodies and organizations in electronic form during the consideration of a particular case, without creating inconveniences for citizens, by integrating the information system of the 
The American Journal of Political Science Law and Criminology (ISSN - 2693-0803)

Published: July 30, 2021 | Pages: 35-45

Doi: https://doi.org/10.37547/tajpslc/Volume03Issue07-06

2021: $5 \cdot 952$

Supreme Court with the information systems of 17 state bodies and organizations.

\section{REFERENCES}

1. Мирзиёев Ш.М. Миллий тараққиёт йўлимизни қатъият билан давом эттириб, янги босқичга кўтарамиз. 1жилд. - Тошкент: «Ўзбекистон» НМИУ, 2017. - 5926.

2. Мирзиёев Ш.М. Буюк келажагимизни мард ва олижаноб халқимиз билан бирга қурамиз. 2-жилд. - Тошкент: «Ўзбекистон» НМИУ, 2017. - 488 б.

3. Мирзиёев Ш.М. Нияти улуғ халқнинг иши хам улуғ, хаёти ёруғ ва келажаги фаровон бўлади. 3-жилд. - Тошкент: «Ўзбекистон» НМИУ, 2019. - 3966.

4. Мирзиёев Ш.М. Миллий тикланишдан миллий юксалиш сари. 4-жилд. Тошкент: «Ўзбекистон» НМИУ, 2020. 4526.

5. Мирзиёев Ш.М. Қонун устуворлигини ва инсон манфаатларини таъминлаш - юрт тараққиёти ва халқ фаровонлигининг гарови. Ўзбекистон Республикаси Конституция қабул қилинганининг 24 йиллигига бағишланган тантанали маросимдаги маъруза. 2016 йил 7 декабрь. // - Тошкент: «Ўзбекистон» НМИУ, 2017. - 48 б.

6. Мирзиёев Ш.М. Эркин ва фаровон, демократик Ўзбекистон давлатини биргаликда барпо этамиз. Ўзбекистон Республикаси Президенти лавозимига киришиш тантанали маросимига бағишланган Олий Мажлис палаталарининг қўшма мажлисидаги нутқ / Ш.М.Мирзиёев. - Тошкент: «Ўзбекистон» НМИУ, 2016. - 56 б.
7. Мирзиёев Ш.М. Танқидий тахлил, қатьий тартиб-интизом ва шахсий жавобгарлик - хар бир рахбар фаолиятининг кундалик қоидаси бўлиши керак. Мамлакатимизни 2016 йилда ижтимоийиқтисодий ривожлантиришнинг асосий якунлари ва 2017 йилга мўлжалланган иқтисодий дастурнинг энг мухим устувор йўналишларига бағишланган Вазирлар Махкамасининг кенгайтирилган мажлисидаги маъруза, 2017 йил 14 январь. - Тошкент: «Ўзбекистон» НМИУ, 2017. - 104 б.

8. Ўзбекистон Республикаси Президенти Шавкат Мирзиёевнинг 19 сентябрь куни Бирлашган Миллатлар Ташкилоти Бош Ассамблеясининг 72-сессиясида сўзлаган нутқи: http://uza.uz/oz/politics/zbekistonprezidenti-shavkat-mirziyeev-bmt-boshassambleyasi-20-09-2017

9. Ўзбекистон Республикаси Президенти Ш.Мирзиёвнинг Олий Мажлисга мурожаатномаси. Халқ сўзи. - 2017 йил 23 декабрь. - № 58(6952).Б. 2. 